\title{
Microwave-assisted eco-friendly synthesis of bis-, tris(indolyl)methanes and synthesis of di-bis(indolyl)methanes catalyzed by fruit juice of Citrus limon under solvent-free conditions
}

\author{
Rammohan Pal \\ Department of Chemistry, Acharya Jagadish Chandra Bose College, 1/1B, A. J. C. Bose Road, Kolkata 700020, \\ West Bengal, India
}

\begin{abstract}
Microwave-assisted efficient and eco-friendly synthesis of bis-, tris(indolyl)methanes and dibis(indolyl)methanes by the reaction of indoles with aldehydes in presence of fruit juice of Citrus limon as catalyst under under solvent-free conditions is reported. The advantages of the protocol are the use of green and inexpensive catalyst, commercially available precursors, simple work-up procedures, high yields and short reaction times.
\end{abstract}

Keywords: Bis-, tris-, and tetra(indolyl)methanes, Microwave irradiation, Fruit juice of Citrus limon, Green and inexpensive acid catalyst, Eco-friendly

\section{Introduction}

Many synthetic chemists have made a great deal of effort to design sustainable and clean procedures to replace the classical synthetic methods [1]. Application of microwave irradiation chemistry to enhance the efficiency and/or selectivity of organic reactions is one of the well-known challenges [2]. Microwave-assisted organic synthesis exploits a variety of factors such as milder and more efficient conditions, high yields and shorter reaction times, energy conservation, formation of purer products, waste minimizationand easier manupulation. Microwave irradiation is well-known to promote the synthesis of a variety of compounds [3-4], where chemical reactions are accelerated because of selective absorption of microwave by polar molecules.

Recently, the coupling of microwave irradiation with polar organic molecules under solvent-free conditions has received notable attention [4]. A literature survey revels example of specific reactions, which do not occur under conventional conditional heating, but could be possible by microwave irradiation [5].

Today, there is a great demand for green and inexpensive acids instead of conventional mineral acids such as $\mathrm{HF}, \mathrm{H}_{2} \mathrm{SO}_{4}$ and $\mathrm{HCl}$ in chemical processes. Mineral acids are corrosive and hazardous catalysts [6]. Fruit juice of Citrus limon contains citric acid which could be acts as an effective acid catalyst by activating the carbonyl group of the aldehydes in organic reactions. Easy preparation and handling, separation and work-up processes, non-hazardous nature and easier waste disposal are among the most common characteristics that makes it a green catalysts.

Indoles and their derivatives are known as an important class of heterocyclic compounds and bioactive intermediates in R \& D and pharmaceutical industry [7]. Bis(indolyl)methanes (BIMs) exhibit a wide range of biological activities such as antimicrobial and antifungal [8], antibacterial [9], analgesic and anti-inflammatory [10], growth promoting [11], antitumor [12] and anticancer [13] activities. Recently, Maciejewska et al. [14] used DNA-based electrochemical biosensors to demonstrate that bis(5-methoxy-3-indolyl)methane considerably reduces the growth of cancer cell lines such as HOP-92 (lung), A498 (renal), and MDAMB-231/ITCC (breast). Tris(indolyl)methanes (TIMs) found in bacteria [15].serve as bacterial metabolic [16] and cytotoxic [17] agents. Due to the versatile applications of BIMs and TIMs, there is contineous interest in the synthesis of these compounds [18-19]. Synthetically, the reaction of indole with aldehyde or ketone produces azafulvenium salts that react further with a second indole molecule to form bis(3-indolyl)methanes [20]. Numberous methods describing the synthesis of bis(indolyl)methanes were reported in the literature employing protic acids [21] include silica sulfuric acid [22], silica supported $\mathrm{NaHSO}_{4} /$ amberlyst-15 [23] and Lewis acids such as iodine [24], lihium perchlorate [25], cupric fluoroborate [26] and silicotungtic acid [27]. Recently, benzoic acid [28] in water, sodium dodecylsulfate (SDS) [29] as surfactant in water, oxalic acid combination with $N$-acetyl- $N, N, N$ trimethylammonium bromide (CTAB) [30] as surfactant in water, metal triflate in ionic liquid [31], Fe(III) salts in ionic liquid [32] and ionic liquid [33] were reported to be efficient for this transformation. Although, ionic liquids are reusable but ionic liquid and surfactants are very expensive. However, there are still some drawback in the catalytic system including the requirment of large [34-35], or stoichiometric amount of catalysts [19,36], long reaction times [28], [34-35] low yields of products [19] and drastic reaction condition for catalyst preparation [37]. 
In continuation of this research, I herein report the first example of the synthesis of bis-, tris(indolyl)methanes and di-bis(indolyl)methanes in presence of fruit juice of Citrus limon a green, inexpensive and easily available acid catalyst by direct reaction of indoles with aromatic and aliphatic aldehydes using microwave irradiation under solvent-free conditions (Scheme 1).

\section{Results And Discussion}

In the present article, a facile and clean route using fruit juice of Citrus limon as a mild and highly efficient acid catalyst for the comparative synthesis of bis(3-indolyl)methanes $\mathbf{3}$ under microwave irradiation condition were described (Scheme 1). I have found that indole / 2-methylindole $(2 \mathrm{mmol})$ when reacted with various aldehydes $(1 \mathrm{mmol})$ in presence of fruit juice of Citrus limon in neutal alumina under microwave irradiation produces bis(3-indolyl)methanes (3a-x) in high yields (Scheme 1, Table 1). When 3-formylindole was used as a aldehydes the corresponding tris(3-indolyl)methanes (3y and $\mathbf{z})$ are formed in similar reaction conditions. The structures of the known products were settled by the comparison of ${ }^{1} \mathrm{H}-\mathrm{NMR}$ and melting points with their literature data and the structures for the unknown products were settled from their analytical and spectral (IR, ${ }^{1} \mathrm{H}-\mathrm{NMR}$ and Mass) data.

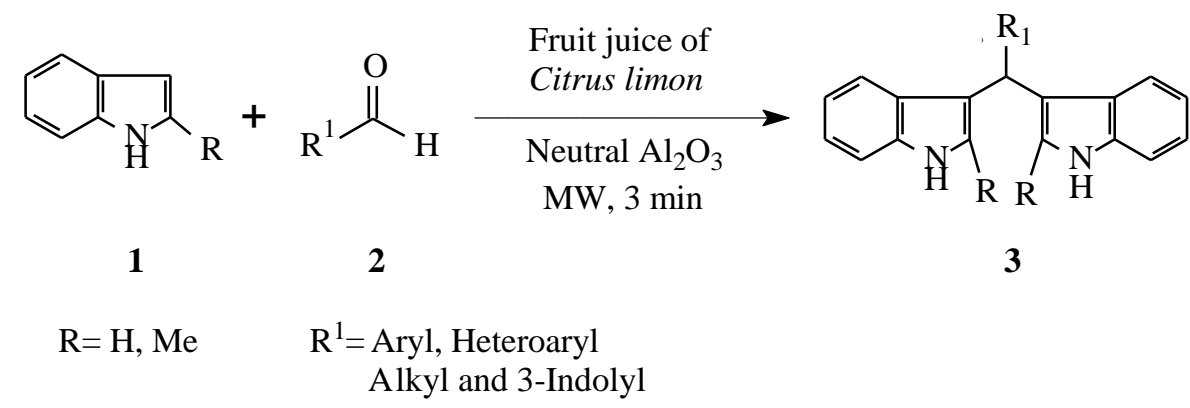

Scheme 1

The scope of application of the presented method is demonstrated by using the various substituted aromatic and aliphatic aldehydes to react with indoles. The procedure was successfully applied for heteroaromatic aldehyde (entry $\mathrm{n}$ ) and the corresponding BIMs was obtained in $85 \%$ yield. The electronic nature of the substituents in the aromatic ring did not show any noticeable effect on this conversion. The long-chain aliphatic aldehydes (entries $\mathrm{o}, \mathrm{p}$ and $\mathrm{x}$ ) also worked well to form the products in high yields. The ether (entries $\mathrm{b}, \mathrm{d}$, e and $\mathrm{r}$ ) and esters linkages (entries $\mathrm{g}, \mathrm{h}$ and $\mathrm{v}$ ) present in the aldehydes were unaffected. The activity of indole and 2-methylindole was found to be almost similar towards the reaction. The results are summarized in (Table 1).

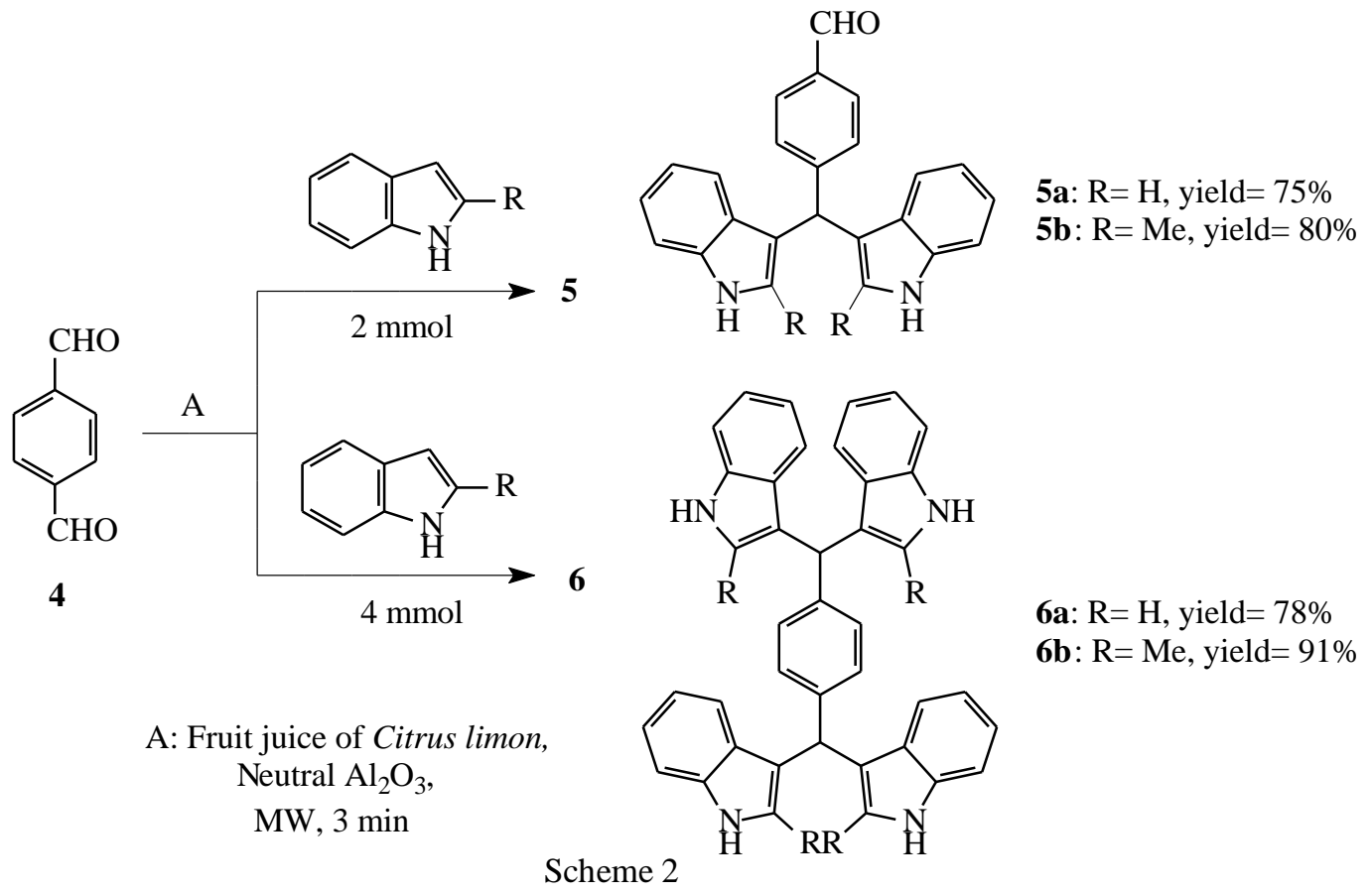


Interstingly, when I used terephthaldialdehyde (4) and indoles in 1:2 ratio, $p$-bis-indolylmethane benzaldehydes (5a [38] and 5b) were obtained in good yields. When 4 molar equivalents of indoles were used, $p$-di(bisindolylmethane)benzenes (6) were obtained in 78\% and 91\% yields of $6 \mathbf{a}$ [38] and $\mathbf{6 b}$ respectively (Scheme 2).

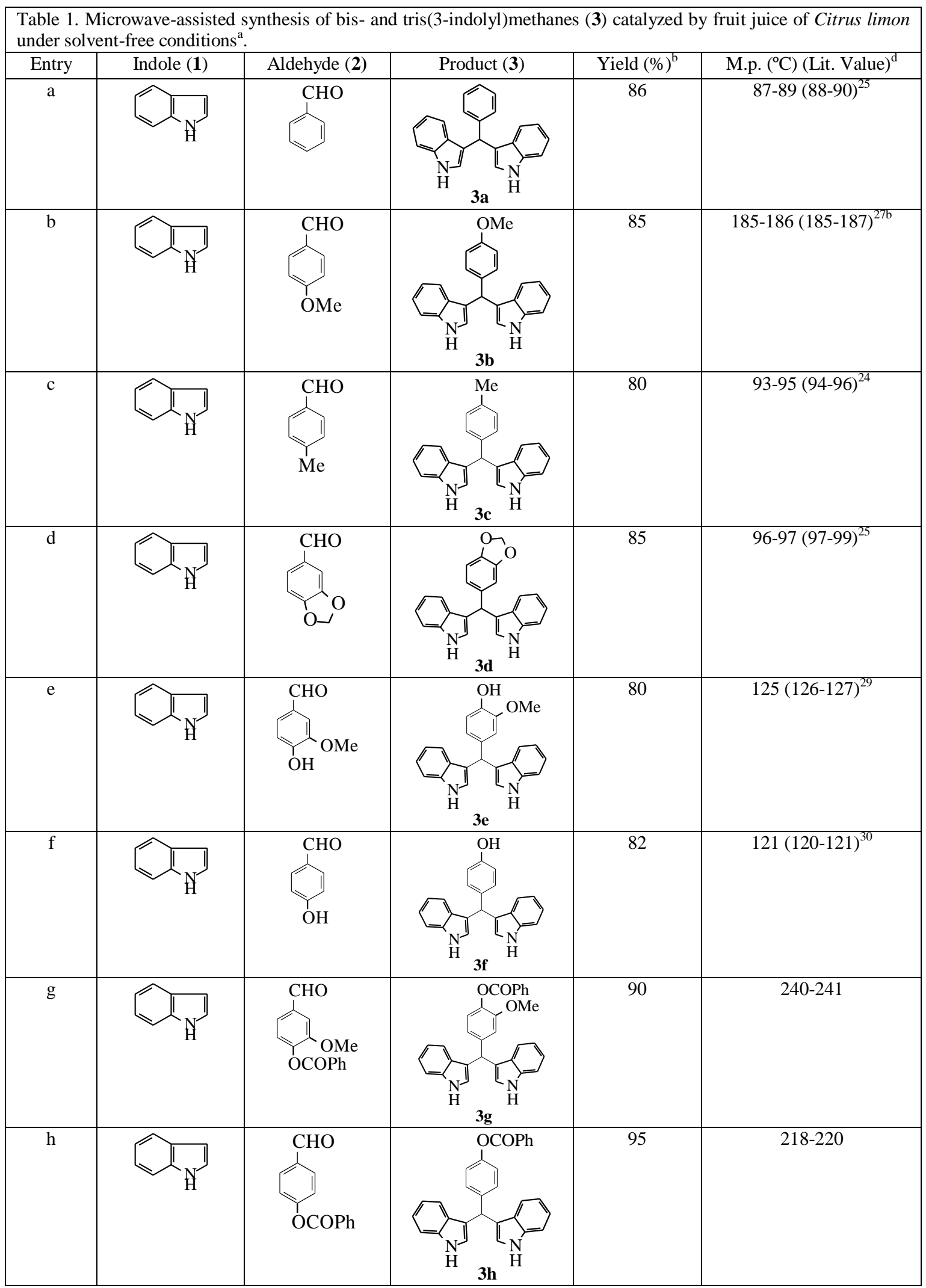


Microwave-assisted eco-friendly synthesis of bis-, tris(indolyl)methanes and synthesis of di(bis

Table 1. Continued

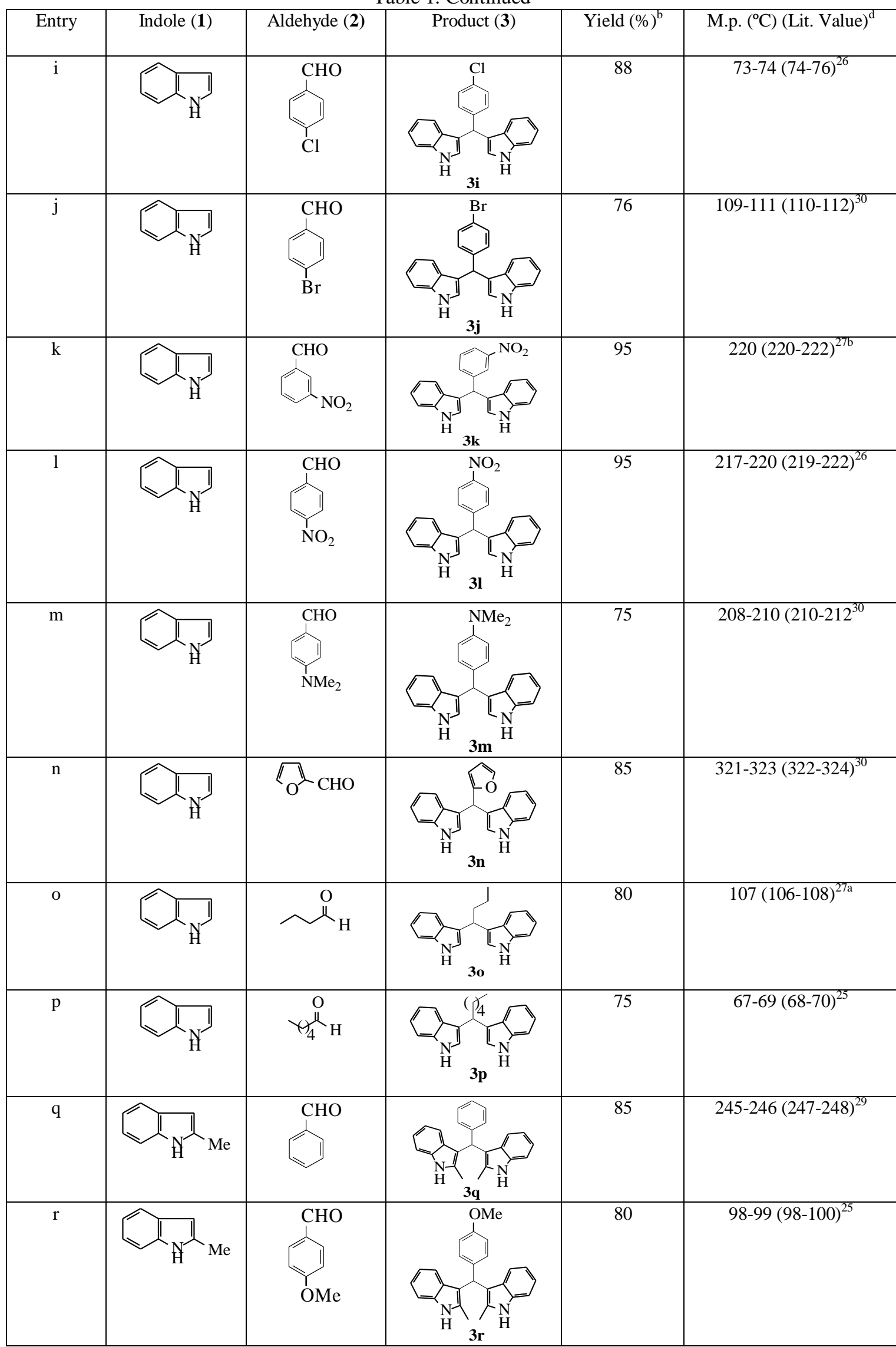


Table 1. Continued

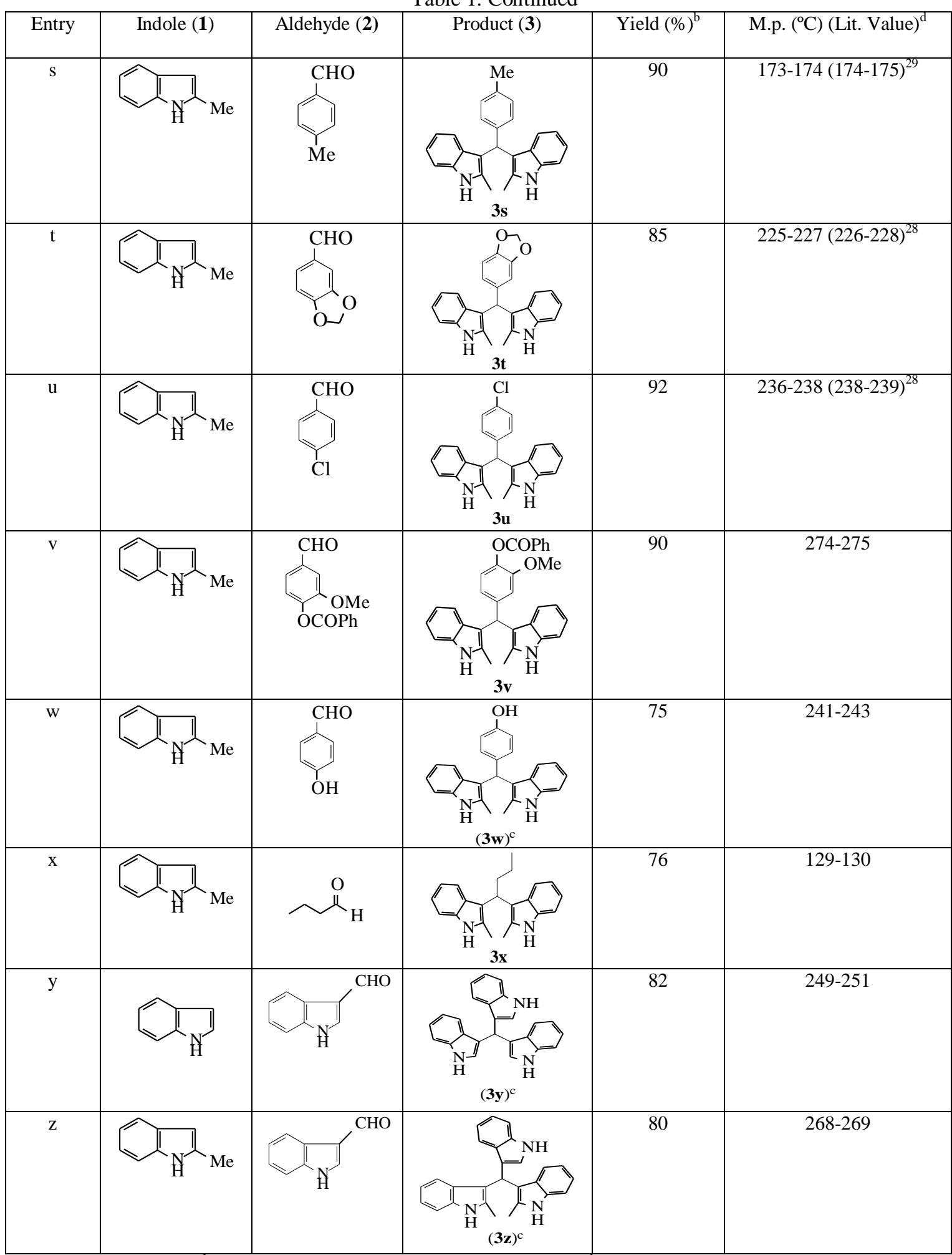

${ }^{\mathrm{a}}$ Reaction time $3 \mathrm{~min} ;{ }^{\mathrm{b}}$ Isolated yield; ${ }^{\mathrm{c}}$ Known compound ref. $23 ;{ }^{\mathrm{d}}$ References for melting point.

This method is also highly chemoselective for aryl aldehydes in presence of ketones and aliphatic aldehydes. For example, when 1:1 mixture of 4-methoxybenzaldehyde and acetophenone was allowed to react with indole in presence of lemon juice in neutral alumina under microwave irradiation, it was found that only 3,3'bis(indolyl)-4-methoxyphenylmethane (3b) was obtained, while acetophenone did not give the corresponding product under this reaction condition. Also, in an equimolar mixture aryl aldehyde and aliphatic aldehyde, it was found that aryl aldehyde were chemosectively converted to the corresponding bis(3-indolyl)methane, but the 
aliphatic ones converted slightly (Scheme 3 ). The reaction was clean and the products were obtained in high yields with out the formation of any by-products.<smiles>COc1ccc(C=O)cc1</smiles><smiles>COc1ccc(C(c2c[nH]c3cc(-c4ccc(C(C)=O)cc4)ccc23)c2c[nH]c3ccc([OH2+])cc23)cc1</smiles><smiles>CCCC=O</smiles>

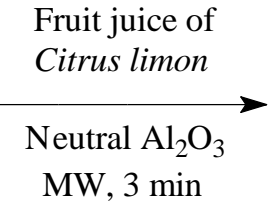<smiles>CCCC(c1c[nH]c2ccccc12)c1c[nH]c2ccccc12</smiles>

Scheme 3

\subsection{Chemicals and Apparatus}

\section{Experimental}

All the chemicals used in the present study are of analytical grade and were obtained from local suppliers. Melting points were determined on a Kofler block and uncorrected. IR spectra were recorded on Perkin Elmer FT-IR Spectrophotometer (Spectrum RX 1) and Jasco FT-IR-4200 Spectrophotometer as KBr pellets. ${ }^{1} \mathrm{H}$ NMR spectra were obtained in $\mathrm{CDCl}_{3}$ or DMSO-d $\mathrm{d}_{6}$ on a Bruker AV-300 (300 MHz) and Bruker AV$500(500 \mathrm{MHz})$ spectrometers using TMS as an internal standard. Mass spectra were acquired on a QTOF Micro Mass spectrometer. Analytical samples were dried in vасио at room temperature. Microanalytical data were recorded on two Perkin-Elmer 2400 Series II C, H, N analyzers. Column chromatograpy were performed on silica gel (100-200 mesh) using petroleum ether $\left(60-80^{\circ} \mathrm{C}\right)$-ethyl acetate mixture as eluents. TLC was carried out on silica gel G.

\subsection{Preparation of fruit juice from the fruits of Citrus limon}

Fruits of Citus limon was purchased from the local market. The fruit's juice was extracted mechanically and centrifuged using Micro Centrifuge (REMI RM-12C). The clear portion of the juice was used as catalyst for the reactions.

\subsection{General procedure for synthesis of bis-, tris-, and tetraindolyl compounds}

A mixture of indoles $1(2 \mathrm{mmol})$, aldehydes $2(1 \mathrm{mmol})$, fruit juice of Citrus limon $(1 \mathrm{ml})$ and neutral alumina $\left(\mathrm{Al}_{2} \mathrm{O}_{3}, 1.5 \mathrm{gm}\right)$ were grinded with mortal and pestle and it was dried. The solid mixture was irradiated under a microwave (LG, MH-4048GW, $480 \mathrm{~W}, 3 \mathrm{~min}$ ). After completion of the reaction, the reaction mixture was diluted with water and then extracted with ethyl acetate. The combined organic layer was dried over anhydrous $\mathrm{Na}_{2} \mathrm{SO}_{4}$ and concentrate under reduced pressure. The obtained crude product was purified by rapid column chromatography on silica gel using petroleum ether-ethyl acetate mixtures to obtained pure bis- and tris (3-indolyl)methanes 3 (Table 1) and p-3,3'-bis(indolyl)methane benzaldehydes (5). Tetraindolyl compounds $\mathbf{6}$ were obtained in similar reaction conditions using 4 molar proportions of indoles. Majority of the compounds were known compounds and characterized from the reported melting points (reffered in Table 1) and ${ }^{1} \mathrm{H}$ NMR data and compounds $\mathbf{3 g}-\mathbf{h}, \mathbf{3 v}, \mathbf{3 x}, \mathbf{5} \mathbf{b}$ and $\mathbf{6} \mathbf{b}$ were unknown. The unknown products were characterized from their analytical and spectral (IR, ${ }^{1} \mathrm{H}$ NMR, ${ }^{13} \mathrm{C}$ and mass) data.

\subsection{Analytical and Spectral data of unknown products}

3,3'-Bis(indolyl)-4-benzoyloxy-3-methoxyphenylmethane 3g (Table 1, entry g). White solid. m.p.: 240$241{ }^{\circ} \mathrm{C}$; IR (KBr) $v_{\max } 3399$ and $3366(\mathrm{~N}-\mathrm{H}), 3057,2966,1725(\mathrm{OCOPh}), 1276,743 \mathrm{~cm}^{-1}$; ${ }^{1} \mathrm{H}$ NMR $(300 \mathrm{MHz}$, 
Microwave-assisted eco-friendly synthesis of bis-, tris(indolyl)methanes and synthesis of di(bis

$\left.\mathrm{CDCl}_{3}\right): \delta 3.68(3 \mathrm{H}, \mathrm{s}, \mathrm{OMe}), 5.90(1 \mathrm{H}, \mathrm{s}, \mathrm{Ar}-\mathrm{CH}), 6.67(2 \mathrm{H}, \mathrm{s}), 6.91(1 \mathrm{H}, \mathrm{d}, J=8.1 \mathrm{~Hz}), 6.99-7.05(4 \mathrm{H}, \mathrm{m})$, $7.17(2 \mathrm{H}, \mathrm{t}, J=7.5 \mathrm{~Hz}), 7.36(2 \mathrm{H}, \mathrm{d}, J=8.1 \mathrm{~Hz}), 7.42(2 \mathrm{H}, \mathrm{d}, J=7.8 \mathrm{~Hz}), 7.49(2 \mathrm{H}, \mathrm{t}, J=7.5 \mathrm{~Hz}), 7.59-7.64$ $(1 \mathrm{H}, \mathrm{m}), 7.94\left(2 \mathrm{H}\right.$, br s, NH), $8.21(2 \mathrm{H}, \mathrm{d}, J=8.1 \mathrm{~Hz})$. MS (ESI) $m / z$ : Calcd for $\mathrm{C}_{31} \mathrm{H}_{24} \mathrm{~N}_{2} \mathrm{O}_{3}[\mathrm{M}+\mathrm{Na}]^{+} 495.17$, Found 495.21. Anal. Calcd for $\mathrm{C}_{31} \mathrm{H}_{24} \mathrm{~N}_{2} \mathrm{O}_{3}$ (472.54): C, 78.80; H, 5.12; N, 5.93\%. Found: C, 78.69; H, 5.07; N, $5.99 \%$.

3,3'-Bis(indolyl)-4-benzoyloxyphenymethane 3h (Table 1, entry h). White crystalline solid. m.p.: 218$220{ }^{\circ} \mathrm{C}$; IR $(\mathrm{KBr}) v_{\max } 3392(\mathrm{~N}-\mathrm{H}), 3062,2950,1723(\mathrm{OCOPh}), 1270,745 \mathrm{~cm}^{-1} ;{ }^{1} \mathrm{H}$ NMR $\left(500 \mathrm{MHz}, \mathrm{CDCl}_{3}\right): \delta$ $5.92(1 \mathrm{H}, \mathrm{s}, \mathrm{Ar}-\mathrm{CH}), 6.67(2 \mathrm{H}, \mathrm{s}), 7.02(2 \mathrm{H}, \mathrm{t}, J=7.5 \mathrm{~Hz}), 7.13(2 \mathrm{H}, \mathrm{d}, J=.5 \mathrm{~Hz}), 7.18(2 \mathrm{H}, \mathrm{t}, J=7.5 \mathrm{~Hz}), 7.36$ $(2 \mathrm{H}, \mathrm{d}, J=8.0 \mathrm{~Hz}), 7.38(2 \mathrm{H}, \mathrm{d}, J=8.5 \mathrm{~Hz}), 7.39(2 \mathrm{H}, \mathrm{t}, J=8.1 \mathrm{~Hz}), 7.50(2 \mathrm{H}, \mathrm{t}, J=7.8 \mathrm{~Hz}), 7.62(1 \mathrm{H} . \mathrm{m})$, $7.95\left(2 \mathrm{H}\right.$, br s, NH), $8.19\left(2 \mathrm{H}, \mathrm{d}, J=9.0 \mathrm{~Hz}\right.$ ). HRMS (ESI) $m / z$ : Calcd for $\mathrm{C}_{30} \mathrm{H}_{22} \mathrm{~N}_{2} \mathrm{O}_{2}[\mathrm{M}+\mathrm{Na}]^{+} 465.1578$, Found 465.1578. Anal. Calcd for $\mathrm{C}_{30} \mathrm{H}_{22} \mathrm{~N}_{2} \mathrm{O}_{2}$ (442.52): C, 81.43; H, 5.01; N, 6.33\%. Found: C, 80.93; H, 4.90; $\mathrm{N}, 6.39 \%$.

3,3'-Bis(2-methylindolyl)-4-benzoyloxy-3-methoxyphenylmethane 3v (Table 1, entry v). White solid. m.p.: $274-275{ }^{\circ} \mathrm{C}$. IR (KBr) $v_{\max } 3401$ and $3375(\mathrm{~N}-\mathrm{H}), 3057,2933,1725(\mathrm{OCOPh}), 1275,743 \mathrm{~cm}^{-1}$; ${ }^{1} \mathrm{H} \mathrm{NMR}$ $\left(300 \mathrm{MHz}, \mathrm{DMSO}-\mathrm{d}_{6}\right): \delta 2.50(6 \mathrm{H}, \mathrm{s}, \mathrm{Me}), 3.55(3 \mathrm{H}, \mathrm{s}, \mathrm{OMe}), 5.97(1 \mathrm{H}, \mathrm{s}, \mathrm{Ar}-\mathrm{CH}), 6.76-6.69(3 \mathrm{H}, \mathrm{m}), 6.92-6.87$ $(4 \mathrm{H}, \mathrm{m}), 7.10(2 \mathrm{H}, \mathrm{d}, J=9.1 \mathrm{~Hz}), 7.21(2 \mathrm{H}, \mathrm{d}, J=8.4 \mathrm{~Hz}), 7.59(2 \mathrm{H}, \mathrm{t}, J=7.5 \mathrm{~Hz}), 7.76-7.71(1 \mathrm{H}, \mathrm{m}), 8.11$ $(2 \mathrm{H}, \mathrm{d}, J=7.2 \mathrm{~Hz}), 10.76\left(2 \mathrm{H}\right.$, br s, NH). MS (ESI) $\mathrm{m} / z$ : Calcd for $\mathrm{C}_{33} \mathrm{H}_{28} \mathrm{~N}_{2} \mathrm{O}_{3}[\mathrm{M}+\mathrm{Na}]^{+}$523.20, Found 523.26. Anal. Calcd for $\mathrm{C}_{33} \mathrm{H}_{28} \mathrm{~N}_{2} \mathrm{O}_{3}$ (500.60): C, 79.18; H, 5.64; N, 5.60\%. Found: C, 79.56; H, 5.58; N, 5.63\%.

3,3'-Bis(2-methylindolyl)-n-propylmethane 3x (Table 1, entry $\mathrm{x}$ ). White solid. m.p. 129-130 ${ }^{\circ} \mathrm{C} .:$ IR $v_{\max }(\mathrm{KBr}): 3385(\mathrm{~N}-\mathrm{H}), 3055,2955,1458,1302,745 \mathrm{~cm}^{-1} ;{ }^{1} \mathrm{H}$ NMR $\left(300 \mathrm{MHz}, \mathrm{CDCl}_{3}\right): \delta 0.95(3 \mathrm{H}, \mathrm{t}, J=7.5$ $\mathrm{Hz}), 1.36-1.44(2 \mathrm{H}, \mathrm{m}), 2.34(6 \mathrm{H}, \mathrm{s}, \mathrm{Me}), 2.38-2.47(2 \mathrm{H}, \mathrm{m}), 4.41(1 \mathrm{H}, \mathrm{t}, J=7.8 \mathrm{~Hz}, \mathrm{Ar}-\mathrm{CH}), 6.97(2 \mathrm{H}, \mathrm{t}, J=$ $7.5 \mathrm{~Hz}), 7.04(2 \mathrm{H}, \mathrm{t}, J=7.5 \mathrm{~Hz}), 7.21(2 \mathrm{H}, \mathrm{d}, J=8.1 \mathrm{~Hz}), 7.62(2 \mathrm{H}, \mathrm{d}, J=7.8 \mathrm{~Hz}), 7.64(2 \mathrm{H}$, br s, NH). MS (ESI) $m / z$ : Calcd for $\mathrm{C}_{22} \mathrm{H}_{24} \mathrm{~N}_{2}[\mathrm{M}+\mathrm{Na}]^{+}$339.18, Found 339.23. Anal. Calcd for $\mathrm{C}_{22} \mathrm{H}_{24} \mathrm{~N}_{2}$ (316.45): C, 83.50; $\mathrm{H}$, 7.64; N, 8.85\%. Found: C, 83.41; H, 7.59; N, 8.97\%.

p-3,3'-Bis(2-methylindolyl)methane benzaldehyde 5b Pink solid. m.p.: 232-234 ${ }^{\circ} \mathrm{C} .{ }^{1} \mathrm{H}$ NMR $(300 \mathrm{MHz}$, DMSO-d $\left.{ }_{6}\right): \delta 2.08\left(6 \mathrm{H}, \mathrm{s}, \mathrm{CH}_{3}\right), 6.01(1 \mathrm{H}, \mathrm{s}, \mathrm{Ar}-\mathrm{CH}), 6.67(2 \mathrm{H}, \mathrm{t}, J=7.5 \mathrm{~Hz}), 6.79(2 \mathrm{H}, \mathrm{d}, J=7.5 \mathrm{~Hz}), 6.89$ $(2 \mathrm{H}, \mathrm{t}, J=7.8 \mathrm{~Hz}), 7.22(2 \mathrm{H}, \mathrm{d}, \mathrm{J}=7.8 \mathrm{~Hz}), 7.39(2 \mathrm{H}, \mathrm{d}, J=8.1 \mathrm{~Hz}), 7.81(2 \mathrm{H}, \mathrm{d}, J=8.1 \mathrm{~Hz}), 9.96(1 \mathrm{H}, \mathrm{s}$, CHO), $10.82\left(2 \mathrm{H}\right.$, br s, NH); MS (ESI) $m / z$ : Calcd for $\mathrm{C}_{26} \mathrm{H}_{22} \mathrm{~N}_{2} \mathrm{O}[\mathrm{M}-\mathrm{H}]^{+}$377.17, Found 377.23. Anal. Calcd for $\mathrm{C}_{26} \mathrm{H}_{22} \mathrm{~N}_{2} \mathrm{O}$ (378.47): C, 82.52; H, 5.86; N, 7.40\%. Found: C, 82.62; H, 5.97; N, 7.13\%.

p-Di[3,3'-bis(2-methylindolyl)methane]benzene 6b Red solid. m.p.: 280-282 ${ }^{\circ} \mathrm{C} .:$ IR $v_{\max }(\mathrm{KBr}): 3390$ $(\mathrm{N}-\mathrm{H}), 3055,2944,1454,1300,746 \mathrm{~cm}^{-1} ;{ }^{1} \mathrm{H}$ NMR (300MHz, DMSO-d $\left.{ }_{6}\right): \delta 2.09\left(12 \mathrm{H}, \mathrm{s}, \mathrm{CH}_{3}\right), 5.87(2 \mathrm{H}, \mathrm{s})$, $6.67(4 \mathrm{H}, \mathrm{t}, J=7.5 \mathrm{~Hz}), 6.88(2 \mathrm{H}, \mathrm{t}, J=8.7 \mathrm{~Hz}), 6.90(4 \mathrm{H}, \mathrm{d}, J=8.4 \mathrm{~Hz}), 7.05(4 \mathrm{H}, \mathrm{s}),, 7.18(4 \mathrm{H}, \mathrm{d}, J=7.8 \mathrm{~Hz})$, $10.71\left(4 \mathrm{H}\right.$, br s, NH). ${ }^{13} \mathrm{C}$ NMR $\left(75 \mathrm{MHz}, \mathrm{DMSO}-\mathrm{d}_{6}\right): \delta 12.05\left(\mathrm{CH}_{3}\right), 38.26(\mathrm{Ar}-\mathrm{CH}), 110.29,111.89,112.33$, 117.84, 118.67, 19.49, 128.29, 131.99, 135.05, 141.52; MS (ESI) m/z: Calcd for $\mathrm{C}_{44} \mathrm{H}_{38} \mathrm{~N}_{4}[\mathrm{M}-\mathrm{H}]^{+} 621.30$, Found 621.25. Anal. Calcd for $\mathrm{C}_{44} \mathrm{H}_{38} \mathrm{~N}_{4}$ (622.80): C, 84.85; H, 6.15; N, 9.00. Found: C, 84.71; H, 6.27; N, 8.89.

\section{Conclusions}

Fruit juice of Citrus limon promotes the condensation of indoles and aldehydes using microwave irradiation under solvent-free conditions. The notable advantages of this procedure are: (a) resonably good yield; (b) shorter reaction times; (c) mild conditions; (d) in tune with green synthesis avoiding toxic reagents; (e) It has a general applicability accommodating a variety of substitution patterns and the products $3 \mathbf{g}-\mathbf{h}, \mathbf{3 v}, \mathbf{3 x}, \mathbf{5 b}$ and 6b are new compounds and may have potectial biological activities. I believe this procedure will play an important role in the preparation of nitrogen heterocyclic derivatives.

\section{Acknowledgements}

Financial support from the University Grants Commission, New Delhi, Government of India (UGC MRP Grant no. PSW-130/11-12-ERO) is gratefully acknowledged.

\section{References}

[1] M. Doble, and A. Kumar, "Green chemistry and engineering”, Elsevier, 2007.

[2] C. Einhorn, J. Einhorn, and J.L. Luche. "Sonochemistry-The use of ultrasonic waves in synthetic organic chemistry", Synthesis, No. 11,1989 , pp. 787-813.

[3] P.H.H. Hermkens, H.C.J. Ottenheijm, and D.C. Ress, "Solid-phase organic reactions II: A review of the literature Nov 95-Nov 96", Tetrahedron, Vol. 53, No. 16, 1997, pp. 5643-5678.

[4] L. Perreux, and A. Loupy, "A tentative rationalization of microwave effects in organic synthesis according to the reaction medium, and mechanistic considerations", Tetrahedron, Vol. 57, No. 45, 2001, pp. 9199-9223.

[5] D. Dallinger, and C.O. Kappe, "Microwave-assistaed synthesis in water as solvent", Chemical. Reviews, Vol. 107, No. 6, 2007, pp. 2563-2591.

[6] M. Hino, and K. Arata, "Synthesis of solid superacid of tungsten oxide supported on zirconia and its catalytic action for reactions of butane and pentane", Journal of the Chemical Society, Chemical Communications, No. 18, 1988, pp. 1259-1260.

[7] R. J. Sundberg, The chemistry of indoles; Academic press: New York, 1996, p 113. 
[8] G. Sivaprasad, P.T. Perumal, V.R. Prabavathy, and N. Mathivanan, "Synthesis and anti-microbial activity of pyrazolylbisindolespromising anti-fungal compounds", Bioorganic \& Medicinal Chemistry Letters, Vol. 16, No. 24, 2006, pp. 6302-6305.

[9] R. Bell, S. Carmeli, and N. Sar, "Vibrindole A, a metabolite of the marine bacterium, vibrio parahaemolyticus, isolated from the toxic mucus of the boxfish ostracion cubicus", Journal of Natural Products, Vol. 57, No. 11, 1994, pp. 1587-1590.

[10] K. Sujatha, P.T. Perumal, D. Muralidharan, and M. Rajendra, "Synthesis, analgesic and anti-inflammatory activities of bis(indolyl)methanes", Indian Journal of Chemistry, Vol. 48B, No. 2, 2009, pp. 267-272

[11] C. Pal, S. Dey, S.K. Mahato, J. Vinayagam, P.K. Pradhan, V.S. Giri, P. Jaisankar, T. Hossain, S. Baruri, D. Ray, and S.M. Biswas, "Eco-friendly synthesis and study of new plant growth promoters: 3,3'-diindolylmethane and its derivatives", Bioorganic \& Medicinal Chemistry Letters, Vol. 17, No. 17, 2007, pp. 4924-4928.

[12] A. McDougal, M.S. Gupta, D. Morrow, K. Ramamoorthy, J.E. Lee, and S.H. Safe, "Methyl-substituted diindolylmethanes as inhibitors of estrogen-induced growth of T47D cells and mammary tumors in rats", Breast Cancer Research and Treatment, Vol. 66, No. 2, 2001, pp.147-157.

[13] S. Safe, S. Papineni, and S. Chintharlapalli, "Cancer chemotherapy with indole-3-carbinol, bis(3'-indolyl)methane and synthetic analogs", Cancer Letters, Vol. 269, No. 2, 2008, pp. 326-338.

[14] D. Maciejewska, I. Szpakowska, I. Wolska, M. Niemyjska, M. Mascini, and M. Maj-Zurawska, "DNA-based electrochemical biosensors for monitoring of bis-indoles as potential antitumoral agents, chemistry, x-ray crystallograph", Bioelectrochemistry, Vol. 69, No.1, 2006, pp. 1-9.

[15] R. Veluri, I. Oka, I. Wanger-Dobler, and H. Laatsch, "New indole alkaloids from the north sea bacterium vibrio parahaemolyticus bio249", Journal of Natural Products, Vol. 66 No. 11, 2003, pp. 1520-1523.

[16] T. R. Garbe, M. Kobayashi, M. Shimizu, N. Takesue, M. Ozawa, and H. Yukawa, "Indolyl carboxylic acids by condensation of indoles with $\alpha$-keto acids", Journal of Natural Products, Vol. 63, No. 5, 2000, pp. 596-598.

[17] J. Li, L. Wang, B. Li, and G. Zhang, "Synthesis and Cytotoxic Activity of N-Acetylated Triindolylmethanes", Heterocycles, Vol. 60, No. 6, 2003, pp. 1307-1315.

[18] M. Chakrabarty, N. Ghosh, R. Basak, and Y. Harigaya, "Dry reaction of indoles with carbonyl compounds on montmorillonite K10 clay: a mild, expedient synthesis of diindolylalkanes and vibrindole A", Tetrahedron Letters, Vol. 43, No. 22, 2002, pp. 4075-4078.

[19] A.V. Reddy, K. Ravinder, V.L.N. Reddy, G.T. Venkateshwer, V. Ravikanth, and Y. Venkateswarlu, "Zeolite catalyzed synthesis of bis (indolyl)methanes", Synthetic Communications, Vol. 33, No. 21, 2003, pp. 3687-3694.

[20] A.K. Mallik, R. Pal, and T.K. Mandal, "Facile formation of bis(3-indolyl)methylarenes by iodine-catalyzed reaction of indole with $\alpha, \alpha^{\prime}$-bis(arylmethylene)ketones and $\alpha$-substituted arylmethyleneketones in dry ethanol”, Indian Journal of Chemistry, Vol. 46B, No. 12, 2007, pp. 2056-2059.

[21] a) B. Gregorovich, K. Liang, D. Chegston, and S. MacDonald, "Reductive C-alkylation", Canadian Journal of Chemistry, Vol. 46, No. 21, 1968, pp. 3291-3300; b) M. Roomi, and S. MacDonald, "Reductive C-alkylation II", Canadian Journal of Chemistry, Vol. 48, No. 1, 1970, pp. 139-143.

[22] D.M. Pore, U.V. Desai, T.S. Thopate, and P.P. Wadgaonkar, "A mild, expedient, solventless synthesis of bis(indolyl)alkanes using silica sulfuric acid as a reusable catalyst", Arkivoc, Vol. 2006, No. xii, 2006, pp. 75-80.

[23] C. Ramesh, J. Banerjee, R. Pal, and B. Das, "Silica supported sodium hydrogen sulfate and amberlyst-15: two efficient heterogeneous catalysts for facile synthesis of bis- and tris $(1 \mathrm{H}$-indol-3-yl)methanes from indoles and carbonyl compounds", Advanced Synthesis \& Catalysis, Vol. 345, 2003, pp. 557-559.

[24] S.J. Ji, S.Y. Wang, Y. Zhang, and T.P. Loh, "Facile synthesis of bis(indolyl)methanes using catalytic amount of iodine at room temperature under solvent-free conditions", Tetrahedron, Vol. 60, No. 9, 2004, pp. 2051-2055.

[25] J.S. Yadav, B.V.S. Reddy, C.V.S.R. Murthy, G.M. Kumar, and C. Madan, "Lithium perchlorate catalyzed reactions of indoles: an expeditious synthesis of bis(indolyl)methanes", Synthesis, No. 5, 2001, pp. 783-787.

[26] G.A. Meshram, and V.D. Patil, "Simple and efficient method for synthesis of bis(indolyl) methanes with $\mathrm{Cu}\left(\mathrm{BF}_{4}\right)_{2} \cdot \mathrm{SiO}_{2}$ under mild conditions", Synthetic Communications, Vol. 40, No. 1, 2010, pp. 29-38.

[27] a) J.T. Li, and S.F. Sun, "Synthesis of diindolylmethanes (DIMs) catalyzed by sillicotungstic acid by grinding method", E-J. Chem., Vol. 7, No. 3, 2010, pp. 922-926. b) J.T. Li, X.H. Zhang, and Y.L. Song, "Efficient synthesis of bis(indolyl)methanes catalyzed by silicotungstic acid under ultrasound irradiation", International Journal of Chem Tech Research, Vol. 2, No. 1, 2010, pp. 341-345.

[28] A.K. Mallik, R. Pal, C. Guha, and H. Mallik, "A convenient, eco-friendly, and efficient method for synthesis of bis(3indolyl)methanes on water", Green Chemistry Letters and Reviews, Vol. 5, No. 3, 2012, 321-327.

[29] M.L. Deb, and P.J. Bhuyan, "An efficient and clean synthesis of bis(indolyl)methanes in a protic solvent at room temperature", Tetrahedron Letters, Vol. 47, No. 9, 2006, pp. 1441-1443.

[30] R. Ghorbani-Vaghei, H. Veisi, H. Keypour, and A.A. Dehghani-Firouzabadi, "A practical and efficient synthesis of bis(indolyl)methanes in water, and synthesis of di-, tri-, and tetra(bis-indolyl)methanes under thermal conditions catalyzed by oxalic acid dihydrate", Molecular Diversity, Vol. 14, No. 1, 2010, pp. 87-96.

[31] X. Mi, S. Luo, J. He, and J.P. Cheng, "Dy(OTf $)_{3}$ in ionic liquid: an efficient catalytic system for reactions of indole with aldehydes/ketones or imines", Tetrahedron Letters, Vol. 45, No. 23, 2004, pp. 4567-4570.

[32] S.J. Ji, M.F. Zhou, D.G. Gu, Z.Q. Jiang, and T.P. Loh, "Efficient Fe ${ }^{\text {III }}$-catalyzed synthesis of bis(indolyl)methanes in ionic liquids", European Journal of Organic Chemistry, Vol. 2004, No. 7, 2004, pp. 1584-1587.

[33] J.S. Yadav, B.V.S. Reddy, and S. Sunita, "Efficient and eco-friendly process for the synthesis of bis(1H-indol-3-yl)methanes using ionic liquids", Advanced Synthesis \& Catalysis, Vol. 345, No. 3, 2003, pp. 349-352.

[34] D. Chen, L. Yu, and P.G. Wang, "Lewis acid-catalyzed reactions in protic media.Lanthanide-catalyzed reactions of indoles with aldehydes or ketones", Tetrahedron Letters, Vol. 37, No. 26, 1996, 4467-4470.

[35] G. Babu, N. Sridhar, and P.T. Perumal, "A convenient method of synthesis of bis-indolylmethanes: Indium trichloride catalyzed reactions of indole with aldehydes and schiff's bases", Synthetic Communications, Vol. 30, No. 9, 2000, pp. 1609-1614

[36] H. Koshima, and W. Matsuaka, "N-Bromosuccinimide catalyzed condensations of indoles with carbonyl compounds under solventfree conditions", Journal of Heterocyclic Chemistry, Vol. 39, No. 5, 2002, pp. 1089-1091.

[37] L. Wang, J. Han, H. Tian, J. Sheng, Z. Fan, and X. Tang, "Rare earth perfluorooctanoate $\left[\mathrm{RE}(\mathrm{PFO})_{3}\right]$-catalyzed condensation of indoles with carbonyl compounds", Synlett, No. 2, 2005, pp. 337-339.

[38]. K.R.M. Naidu, S.I. Khalivulla, P.C. R. Kumar and O. Lasekan, " $\mathrm{KHSO}_{4}-\mathrm{SiO}_{2}$ catalyzed facile synthesis of bis(indolyl)methanes", Organic Communications, Vol. 5, No. 3, 2012, pp. 150-159. 